\title{
Between historical heritage and policy learning: the reform of public research funding systems in Poland, 1989-2007
}

\author{
Julita Jabłecka and Benedetto Lepori
}

\begin{abstract}
This paper provides an account of the reform of the public research funding system in Poland between 1989 and 2007, a period which includes the dramatic change after the breakdown of the Communist regime with the creation of a completely new system of research funding, yet still characterized by strong centralization; a lock-in phase until 2000 where only minimal changes happened; and a new reform period afterwards leading to a more decentralized and layered structure with a better separation between research policy and research funding. Our analysis displays strong elements on continuity and path dependency in this evolution, but at the same time the lasting influence of the western European model of research policy in the long run (especially after Poland joined the European Union); moreover, it shows how deeply reform in research funding has been embedded in the national context and in the whole process of reform of political institutions in the country.
\end{abstract}

$\mathrm{T}$ HIS PAPER PROVIDES an account of the reform of the public research funding system in Poland between 1989 and 2007. The changes immediately after the collapse of the Communist regime in the years 1989-1991 were revolutionary and led to the creation of a new organizational structure - the State Committee for Scientific Research - which took the responsibility for almost the whole research budget, as well as for the establishment of a new set of funding instruments. Despite the fact that Polish reform has never been explicitly proclaimed by the policy-makers to be inspired by any particular example of research funding organization from abroad, a look at the debate shows that an important element was reference to the

Julita Jabłecka (corresponding author) is at the Centre for Science Policy and Higher Education, University of Warsaw, Str. Nowy Swiat 69,00-046 Warsaw, Poland; Email: j.jablecka@ uw.edu.pl; Tel: 482282607 46. Benedetto Lepori is at the Centre for Organizational Research, Faculty of Economics, University of Lugano, via Lambertenghi 10a, 6904 Lugano, Switzerland; Email: blepori@unisi.ch.

The authors gratefully acknowledge comments from three anonymous referees which were very helpful to improve the paper, as well as advice from Slavo Radosevic. research council model implemented in other European countries and the USA.

However, the organizational setting implemented in Poland differed significantly from all other known solutions at the beginning of 1990s. From 1991 for almost a decade only very minor changes took place, while since 2001 the system has witnessed a substantial but more gradual change towards solutions more similar to those found in most European countries, with the establishment of a research ministry and first steps towards a separation between research policy and allocation of research grants.

This account raises a number of broad questions which are of general interest for scholars studying research policy. A first issue concerns the factors explaining the evolution of Polish research policy and, especially, why the system was so stable for almost a decade after the radical reforms at the breakdown of the Communist regime. Second, one would like to understand why the system created in 1991 was so different from in other European countries despite reference to models abroad; and how lessons about ideas and policy instruments have been incorporated by actors into the domestic political process. Third, it is relevant to look at to what extent the chosen model is related to national specificities, but also to the heritage of the Communist 
Julita Jabłecka is a research fellow at the Centre of Science Policy and Higher Education, University of Warsaw. She received her PhD in economics and her habilitation degree in management science from University of Warsaw. In 1984 she was in the USA as a Fulbright Fellow and in 1990 was an advisor to the first post-Communist Polish Government responsible for the preparation of new science policy institutions and funding instruments. She has been a member of the Committee of Science Studies at the Polish Academy of Sciences since 1990 and its deputy chairman since 2007. She has been involved in many national and international projects. Her major interests are science and higher education policy, management and structures, peer review and the role of universities in knowledge-based economy.

Benedetto Lepori obtained his degree in mathematical physics at the University of Rome in 1988 and a PhD in communication sciences at the University of Lugano in 2004 with a thesis on the Swiss research policy. He is head of the research unit on management and performance of higher education and research institutions in the Faculty of Economics of the University of Lugano, where he also teaches research policy and grant proposal writing. His research interests cover the broad domain of S\&T indicators, with a focus on indicators on public funding and on higher education institutions, comparative studies of research funding and studies of steering and governance of higher education. $\mathrm{He}$ is currently involved on different research projects and contracts at the European level, including the higher education program of the European Science Foundation, various contracts and studies financed by the European Commission and the ERAWATCH research observatory.

system (despite formal rejection of its principles during the reform process) and how international policy transfer influenced this path (both in the early reform phases and in the recent changes). This is thus mostly a national case study, even if it should be seen in the broader context of the Europeanization of central and eastern European countries.

These questions relate to more general conceptions about institutional and policy change, which we discuss in the second section, to provide some theoretical grounding to our analysis. The third section presents a historical overview of the evolution of Polish research funding in the considered period, while the fourth section is devoted to a discussion of the empirical results in the light of three main concepts, namely path dependency, policy learning and policy streams. Finally, we provide some general conclusions on patterns of change in research policy across time.

This study has been done in the framework of a comparative project on public funding of research in central and eastern European countries funded by the European Union 6th Framework Program project, PRIME. Information on the Polish case includes the analysis of published articles, interviews, official documents and internal unpublished documents from government organizations, as well as the reconstruction of main research funding flows and their evolution in the past decade (Lepori et al, 2009). Another source of information is interviews with the main political actors involved in the reforming process. Finally, one of us actively participated in the reform in early 1990 and thus the account of changes also includes participant observation.

\section{Theoretical approaches}

Scholars have developed different approaches to explain institutional and policy changes. Already limited to institutionalists approaches, a well-known review of the field distinguishes between historical institutionalism, rational-choice institutionalism and sociological institutionalism (Hall and Taylor, 1996), even if other reviews might use a slightly different terminology (Peters, 1995). While these approaches agree in attributing a key role to institutions in the evolution of policy domains, they assume largely different positions concerning two key aspects of institutional change:

1. The relationship between actor's choices and behavior on the one hand; institutions on the other. Rational-choice theories largely consider institutions as exogenous sets of rules which limit actor's choices, but then conceive of actors as rational and behaving strategically to maximize their utility inside this rule system (North, 1990). Sociological institutionalism embraces a broader view of institutions as cognitive and social constructs endogenous to the system itself, while an actor's beliefs and preferences are also institutionally constructed. Their behavior is thus driven by conformity to social norms and values more than by individual actor's interests.

2. How institutions are generated and change across time. Rational-choice approaches consider institutions as purposeful constructions by actors to organize collective activities, but also to distribute and manage power (card decking; McCubbins et al, 1987). Thus institutions change or break down as soon as they become dysfunctional, or when alternative institutional arrangements provide actors with a more attractive solution. Sociological and historical institutionalists emphasize the lasting stability of institutions even in the light of changing technological, social, economic and political environments, changing stakeholders' preferences and institutional competition (Stacey and Rittberger, 2003: 867) and the extent to which institutional change is bound by existing norms and beliefs. In this context, appropriateness is more important than functionality for institutional change.

There are good reasons to consider these approaches as more complementary than alternative in the analysis of major policy changes (Hall and Taylor, 1996). This is particularly relevant when studying radical policy reforms like those in central and eastern Europe (Greener, 2002) where we are faced with periods with very different dynamics of change.

In the next section, we provide a discussion of three issues which are central for our account of Polish research policy. These are:

1. The temporal dimension of changes in political institutions and the influence of history on today's 
political institutions (path dependency).

2. The role of ideas in the policy processes and how actors learn to address new problems (policy learning).

3. The role of political actors in shaping policy change, especially when specific opportunities arise to promote major reforms (policy entrepreneurs).

\section{The legacy of history and path dependency}

Historical institutionalism has largely focused on the enduring effect of the history on today's configuration of political institutions and provided rich descriptions of how national systems keep their distinctive characteristics because of past events which constrain today's choices (Steinmo et al, 1992). Beyond this largely descriptive approach, work on path dependency has sought to provide a more rigorous foundation to the idea that 'history matters', by drawing on parallel work by economists on technological trajectories (David, 1985; Arthur, 1989).

The notion of path dependency has been grounded in the existence of positive feedback and increasing returns; past choices not only constrain the range of options, but favour choices which reinforce the structures in place providing stability to a course of events (path) selected at the beginning. In economics, positive feedback is explained through technological irreversibility and collective effects, while in political sciences these have been sought in the characteristics of political institutions (Pierson, 2000). The moment of setting the path dependency into motion represents a critical juncture (Collier and Collier, 1991), which is characterized by the adoption of a particular institutional arrangement from among two or more alternatives. In this moment, small and contingent causes have large and longterm consequences (Pierson, 2000; Mahoney, 2000). Many authors suggest that the initial phase is characterized by unconstrained choice, while others state that history always matters and behavior occurs in a specific historical setting and is influenced by it (Sydow and Koch, 2005: 10).

Unlike sociological institutionalism, which tends to embrace a view of institutional change in terms of punctuated equilibrium with long phases of stability interrupted by revolutionary changes (Scott et al, 2000), path dependency is compatible with gradual change, whose direction is bound by past trajectories (Thelen, 1999). However, in the strongest versions path transformation is presumed to be highly unlikely except through rare radical ruptures often associated with violent external shocks (Djelic and Quack, 2007: 161).

The recent literature concentrates on mechanisms of change. Pierson (2000) sees external shocks as the main source of large-scale institutional change. Other scholars have shown other circumstances when a change of path occurs: if a paradigm shift takes place (Hall, 1993), if power-holders are successful in constructing the need to change that would legitimize path-departing reforms (Cox, 2001). Moreover, empirical work shows that path transformation of political institutions cannot always be traced to single ruptures, but may come about through gradual succession and a series of incremental steps and junctures (Djelic and Quack, 2007). Conversion is a process in which existing institutions are reoriented to serve new purposes or reflect new power dynamics; in a layering process an institution is changed incrementally as additional rules or structures are added on the top of what already exist (Thelen, 2003).

When looking at central and eastern European countries from this perspective a number of relevant questions emerge. The first concerns the features of political decisions in the critical moment at the breakdown of the Communist regime (Stark and Burszt, 1992), which is an almost ideal candidate for a critical juncture setting a new path into motion. A related question concerns to what extent decisions in this revolutionary phase were influenced by history and existing institutions. Finally, one would look at the characteristics of the path (inertia vs. gradual change) and to what extent these have been determined by the choice of the path itself.

\section{Policy learning and international policy transfer}

The concept of policy learning relates to another dimension of policy change, namely how policy actors make a deliberate attempt to adjust the goals or techniques of policy in response to past experience or new information (Hall, 1993; Braun and Benninghoff, 2003). It is thus rooted in traditions focusing on the role of ideas as driving forces for policy (Heclo, 1974), but also in sociological institutionalism where institutions identify and then adapt to a changing environment through a trial-and-error process, while changes in policies and practices need to be legitimated by new rationales and beliefs (Olsen and Peters, 1996).

The literature has distinguished between orders of learning (Hall, 1993):

- In first-order learning, only changes in the settings of policy instruments take place; these are likely to be incremental, as a result of routinized, satisfying behavior.

- Second-order learning occurs when the instruments used to achieve policy goals are modified but the paradigm goals remain the same.

- Third-order learning means a paradigm shift, when the framework of ideas for interpreting the world is modified. These frameworks determine the goals that policy-makers attempt to achieve as well as the nature of the problems they attempt to address (Greener, 2002: 163). Third order learning is considered difficult to achieve and mostly related to external shocks and profound changes 
in the power of different coalitions of actors sharing the same basic beliefs (advocacy coalitions; Sabatier, 1987).

The breakdown of the Communist regime is a case where actors in research policy are confronted with a new problem or puzzle, namely how to design a framework for research policy in a radically different social and economic context; moreover, profound changes in the composition of advocacy coalitions take place. It is thus highly relevant to inquire how actors learned to address this problem and to what extent the coming to power of groups marginalized under the Communist regime contributed to this process and influenced the nature of solutions borne.

A further issue concerns the extent to which actors in this process made use of ideas and solutions already existent in other countries, especially the United States and western Europe, thus linking the concept of policy learning with the literature on the processes involved in international policy transfer and policy diffusion (Dolowitz and Marsh, 2000). This tradition distinguishes between different gradations of transfer, from direct transfer of policy instruments and programs (hard transfer) to the soft transfer of ideas, concepts and attitudes (Smith, 2002: 6). Most authors assume that policy transfer results from a rational judgment of decision-makers: we can find (bounded) rationality in a selection process of policy ideas from the past or from other settings (including other countries) and in adaptation processes through imitation, copying or modification (Stone, 2000; Rose,1993; James and Lodge, 2003). Other authors stress the organizational-cultural processes involved in learning, which often have more to do with rituals and legitimacy than with a process of optimization (Argyris and Shon, 1978).

\section{Policy processes, streams and entrepreneurs}

Policy change obviously has a process dimension, namely through which processes and sequences of actions problems come to the policy agenda (problem stream; Kingdon, 2003), policy alternatives are formulated (policy stream) and finally how political decisions are finally taken and implemented (political stream). While rational-choice approaches conceive this process as rational with actors looking for the best solutions to emerging problems, normative institutionalism assumes that the repertoire of answers to policy problems is largely driven by solutions already in place. Thus, there are strong cognitive and intellectual limitations of the actor's behaviour (Olsen and Peters, 1996; Braun and Benninghoff, 2003), implying that they do not make optimal choices but tend accept satisfying solutions which match their beliefs and expectations.

In its extreme version this approach considers problems and solutions as two independent streams, where solutions are developed whether or not they

\section{Two major characteristics of policy entrepreneurs: the patience to wait for the right moment for pushing for reforms (which cannot be foreseen in advance), and the pragmatism to promote a satisfying rather than an optimal solution}

respond to a problem and, once a problem is put on the political agenda, solutions are picked up from the available set rather than sought through a rational search process (garbage can model; Cohen et al, 1972; Kingdon, 2003). The political process creates policy windows, open for only short periods, where (largely by chance) different conditions for policy change take place. Alternatives proposed are associated with a problem perceived as significant; proposed solutions receive the direct backing of major political advocates having an interest in promoting them (Goldstein and Keohane, 1993); the moment (political and economic) is favorable, the alternatives chosen are technically feasible, and the policy ideas are not too difficult to explain to the public and to decision-makers. In these situations, some individuals - called policy entrepreneurs (Kingdon, 2003) typically play a critical role in pushing for the reforms, in promoting new ideas and, finally, in tying together the different streams by negotiating acceptable solutions for the involved actors. This account of policy change lets two major characteristics of policy entrepreneurs emerge: the patience to wait for the right moment for pushing for reforms (which cannot be foreseen in advance), and the pragmatism to promote a satisfying rather than an optimal solution.

\section{A brief history of Polish research policy and funding, 1989-2007}

Before World War II, the Polish system of higher education and research was based on a western pattern. Most research effort was concentrated in universities organized according to the Humboldtian liberal university model with academic freedom, research autonomy and self-governance; such a system was seen as the most functional for science (Małkowski, 1992).

After World War II, during the era of Communist rule, the organization and financing of $R \& D$ was subordinated to political directives and central planning. Science was subdivided into the higher education sector; branch institutes reporting to various ministries; and the sector of the Polish Academy of Sciences (PAS), which took at the same time the 
functions of a learned society, an administrative body and a research sector with its own institutes. The system of centrally planned large research programs, set up in 1971, tried to overcome the sectoral division of research and to enable implementation of social priorities. This system gradually encompassed all R\&D institutions (Amsterdamski and Jabłecka, 1993).

The responsibility for science policy and for a heavy and detailed centralized control of science belonged to the State Committee for Science and Technological Progress (KNIPT), more precisely to its executive presidium, composed of government members. The Office for Technological Progress and Implementations (UPTIW), headed by the under-secretary of state, at the same time also the KNIPT secretary, had responsibilities similar to a ministry of science. As we shall see, this organization was to play a relevant role in the reforms.

\section{The reforms of 1989-1991}

The process of change started after the political break of 1989, when Tadeusz Mazowiecki formed a new government. The elaboration of a new legislation on a research funding system was the undertaking of KNIPT chaired by Vice-Prime Minister, Jan Janowski, and Under-Secretary of State, Stefan Amsterdamski, the head of the KNIPT Office (UPTIW). In September 1989 the KNIPT chairman set up a governmental advisory team headed by W Findeisen to prepare guidelines for a new law. In February 1990 the government adopted the guidelines, recommending that further legislative work be undertaken.

The reform of the research funding system proposed by the KNIPT chairman was based on principles which changed radically the pre-reform policy assumptions (Amsterdamski and Jabłecka, 1993).

First, the administrative governance over science would be replaced with joint efforts on the part of the government and the research community in terms of defining science policy and its funding. To this end, it was proposed that a council for scientific research (its name later changed for formal requirements into a 'state committee') should be established affiliated to the Council of Ministers, with the majority of members elected by the research community.

Second, different funding instrument were foreseen for basic and applied research, managed by two separated council committees. Competition for peerreviewed research projects was proposed as the basis for the allocation of government funding, while basic research was to be funded also through institutional (statutory) funding. Scientific excellence was intended as an important criterion for funding, enabling the introduction of structural changes of research institutions. Moreover, the commercialization of research results should not be funded by the science budget.
Third, the influence of the ministerial levels and intermediary bureaucratic levels on governmentfunded research should have been eliminated and the funds allocated by the council would be transferred directly to the research institutions and teams.

The task of preparation of the proposal was transferred to a task force in UPTIW headed by Stefan Amsterdamski. After extensive debates at the KNIPT meetings, the final draft was completed and after inter-ministerial consultation sent to the parliament. Work on the draft bill in the relevant parliamentary committee started in September 1990. During the legislative process a number of elements were formulated with greater precision, but there were very few essential changes including those on active voting rights to a collegial body composed of (elected) representatives of the scientific community (the KBN), extended to doctorate holders, alongside professors.

The KBN received at its disposal the whole science budget and was empowered with a dual role: the strategic responsibilities of a ministry of research in research policy and funding tasks usually managed by research councils. The committee's chairman was, at the same time, nominated by parliament as a member of the government. The deputy chairman, the secretary of the KBN, headed the KBN office, made up of administrative staff. At its highest structural level there was a KBN in the narrow sense, consisting of five ministers and 12 scientists elected by the scientific community, representing the disciplinary divisions of the Commission for Basic and for Applied Research. All decisions were made by the KBN members by voting while the chairman had only the right to veto, which could in turn be overruled by the KBN. Apart from representatives of business and local government, the commissions were composed of professors elected by the research community. Decisions concerning science policy were made by the KBN at the top level; decisions on institutional funding were made by the commissions; while the divisions appointed members of the sections evaluating research projects and decided on project funding.

There were six channels of funding:

1. The statutory (institutional) funding of research organizations, including higher education faculties;

2. The investments;

3. Research projects, (the grant system);

4. Goal-oriented projects, initiated by potential business users of results and co-funded by the $\mathrm{KBN}$;

5. International cooperation; and finally

6. Activities supporting research.

All financing, except funding for support activities, was granted directly to research entities or investigators.

Besides the bill preparation the governmental task force worked on the funding instruments. The arrangements of peer-review process and organization 
of the grants and goal-oriented projects and provisional system of institutional assessments were ready when the KBN was constituted in 1991. The other instruments were elaborated gradually in the next years.

\section{From stability to a new reform process}

For almost a decade after 1991 there were only incremental changes of policy instruments. Further reforms began in 2000 with amendments to the Act on the KBN. The name of the KBN office was replaced by a ministry of science; then, the chairman of the KBN became the Minister for Science. He took over most of the KBN's collegial authority and responsibilities in the field of policy formulation and implementation (funding decisions), while the KBN itself became mainly an advisory body. A further important change in 2002 was the delegation of responsibility for targeted projects to the Society of Engineering Associations (such a possibility was introduced in the 1991 Act but not used for more than a decade).

The next step came from a new Minister of Science after the government change in 2002. The elaboration of new regulations was finished in 2004 after a extensive consultation process. The new Act on research funding, of 2004, kept a centralized structure in the form of the Ministry of Science and Information Technology with a research council (RC) connected to it. Ministry responsibility covered both strategic and executive decisions. The Research Council, which replaced the KBN, was an advisory body to the minister, in the areas of both policy formulation and funding. For the first time, the chairman of the $\mathrm{RC}$ and the minister became separate positions; the latter gained decisive powers, including all funding decisions, made upon the recommendations of the RC.

These changes were sometimes labelled as 'a shift from the democratic model to the ministerial model' and met with some resistance on the part of the academic community. The Act of 2004 also introduced new funding instruments such as development projects and projects of international cooperation within the European Union Framework Program (FP), as well as a national research FP funding research on policy-relevant themes.

The process was continued by the next government and led to two Acts: on the National Research and Development Centre (NCBR) and an amendment to the Act on financing science. The new legislation was prepared in 2006 and passed by the parliament in 2007.

The NCBR is an agency, semi-independent from the ministry, funding strategic research programs which require cooperation between large research teams, as well as large facilities in applied sciences and technology, organizing peer review, supporting the mobility of scholars and fulfilling other tasks commissioned by the Minister of Science. The agency is financed from budgetary funds and from external money in the form of structural funds and private funding. The NCBR director is selected through open competition and is advised by a board made up of scientists and representatives of business and NCBR administrative staff.

The ministry announced its willingness to continue the reforms and to establish a research council supporting basic research, an idea which was adopted by a new government established in 2007 . The stated goal is thus in the next years to decentralize the financing system, shifting financing and implementation of research projects from the Ministry of Science to the newly established institutions.

\section{Creating the path: the radical reform and its historical heritage, 1989-1991}

Historical analysis leads to a periodization of Polish research policy in three phases, with very distinct patterns of change: a phase of radical change in a short time (1989-1991), a phase of substantial stability (1991-2000), and finally a sequence of more gradual changes leading to a further restructuring of research policy and funding (2000-2007). In the following, we analyze these phases through the lenses of the concepts introduced in the second section, thus addressing the following three question areas:

1. Do we observe path dependency and path generation? Is historical evolution influenced by the past?

2. How did policy actors/coalitions learn when faced with new political problems? How is this learning translated into practical solutions?

3. How is the political process organized? What role did policy entrepreneurs have in promoting change?

\section{The historical roots of a paradigmatic change}

The period 1989-1991 can be characterized as a phase of paradigmatic change, where the basic concepts of research policy and funding were profoundly modified. The Polish system switched from a highly centralized and state-controlled system to a 'Republic of Science' policy (Polanyi, 1962), where all decisions concerning funding were in the hands of the $\mathrm{KBN}$, based on principles of competition and evaluation of scientific quality. The establishment of a new funding organization and new funding instruments constituted measures for achieving these new goals.

This is coherent with concepts of policy change advocating that paradigmatic change is possible only in situations of external shocks, in this case the collapse of the Communist system. Since the system of research funding was embedded in the whole macrosystem of national economy, its changes created a new environment which required the adjustment of research policy institutions. 
However, this radical reform had roots in Polish history, both in the pre-Communist and in the Communist period. First, a significant feature of most Polish citizens, and especially the research community, was hostility toward and lack of confidence in the state and central administration, developed in the period of oppression of Poland between the end of the 18th century and World War I, as well as during 45 years of Communism, which was never accepted at least by the scientific elites. On the other hand the period of Poland's sovereignty between 1918 and 1939 saw the development of self-management of research institutions, and academic freedom formed academic preferences which survived the period of totalitarian regime among the scientific elites. Then, the atmosphere of distrust of all administration and resentments seriously affected the content of particular provisions (Amsterdamski, 1993). The proposed model of the KBN, with its separation from political and administrative influence, was based on these preferences.

In Polish reform, creating a new path and rejecting the past resulted in a denial of every organizational and political principle, even if some of these principles, such as research funding by various sectoral departments or the involvement of politicians in science policy formulation, are common in democratic countries.

\section{Urgency and learning}

However, looking at the organizational structure, continuity with the Communist regime appears quite strong. The organization of the KBN was similar to the Communist KNIPT and both settings represented highly centralized models of research funding (Lepori et al, 2009). Of course the basic principles of research policy and the role of the research community were different. However, one should not undervalue the importance of these institutional features in designing the interaction between policy and the research system (Bonaccorsi, 2007).

We can advance some arguments to explain continuity of organizational structures vs. paradigmatic changes in the basic principles. A first relates to the fact that it would appear difficult to master at the same time paradigmatic changes both in basic principles and in organizational structures, since this would exceed the cognitive capabilities of the involved actors. A second relates to the limitations of policy learning when actors are faced with sudden and unexpected changes: we expect that learning takes place mostly by recombining existing solutions rather than by designing new ones and this is especially relevant for organizational structures, where there was no past tradition of alternative models. Notions such as the separation between policy and funding, delegation to independent agencies, and intermediaries were developed in research policy only after World War II to address the antinomy between steering by the state and autonomy of research in a more differentiated way (Braun, 2003) and thus had no roots in the Polish context.

This framework also influenced the interpretation given to the American National Science Foundation model, which was seen as a single body funding basic research and governed by scientists rather than as a part of a more complex institutional setting of research policy. The short time available for reforms and the closure of these countries under the Communist regime led to few opportunities for international transfer and learning, beyond the general reference to the research council idea, however reinterpreted to match the basic belief in the 'Republic of Science' and to make it credible.

Moreover, the reform was undertaken in a situation of urgency and the priority was to finalize it as quickly as possible. Thus, there were voices in the group of reformers proposing different settings and pushing towards a polycentric model, with basic research funded by a number of specialized disciplinary agencies, but they finally supported the proposed model as a starting point, assuming that it would gradually evolve towards a system closer to that of western European countries.

This contrasts with the process for the development of new funding instruments, especially of grants and goal-oriented projects, which was based on intensive international policy learning, founded on detailed information about funding rules and peer review of projects, as well as deeper knowledge gathered during a study tour in the USA and Canada. The choice of arrangements was based on several criteria: consistency with the cultural pattern of the prospective research council; general decisionmaking rules; the solutions had to be the least vulnerable to the deviations and dysfunctions associated with habits developed during the several decades of the Communist system (Jabłecka, 1992).

\section{Tying together the reform: entrepreneurs, new and old elites}

To understand why such a radical reform was possible we need to look more precisely to the decisionmaking process and to the involved actors. Of course, the intellectual roots of the reform came from scientific circles near Solidarity and especially from Society for the Advancement of Science (TPKN). Most opposition participants to the subgroup on science in the spring 1989 round-table negotiations between the Communist government and Solidarity came from these circles. The group was chaired by Stefan Amsterdamski, an outstanding philosopher of science and a member of the TPKN with a strong academic reputation, who carried out research for several years in the USA, France and Germany and was familiar with the structure of US research funding agencies.

Competing reform proposals soon emerged. One proposal was drafted by TPKN, another by the group of government experts led by Professor 
W Findeisen, former rector of Warsaw Technical University (Findeisen, 1993). However, in December 1989, Amsterdamski assumed the duty of the KNIPT secretary and thus became the main driving force for the reforms. The KNIPT chairman, Jan Janowski, subsequently co-opted some new members to a composition inherited after Communist rules, including several TPKN members, to ensure a balance between the representatives of various institutional interests. The KNIPT was an empowered decision-making authority instead of having advisory functions and had to legitimize the project in the scientific community.

Co-opting the opposition elites in the organizational structure inherited from the Communist regime was then a key for the success of the reform process, since it led to the merging of the different proposals and avoided open conflicts. It helps also to explain why the new ideas on research policy were infused in organizational structures inherited from the Communist regime, thus effectively transforming the KNIPT into the predecessor of the KBN.

Moreover, because the KNIPT decision-making procedures were not determined by any regulation, the vice-prime minister was free to introduce procedures of voting which made the rejection of the reform proposal practically impossible. Once the proposal was approved by the KNIPT, external groups refrained from requesting additional changes for fear of blocking the reform. Thus, in a political system which after the Communist period lacked the procedural rules to manage an open and democratic debate, the reform process was managed in a centralized and authoritarian way inside the old structures. In fact the reformers had hardly any choice, since developing a consultation process might have delayed the reform.

This account displays the central role of a few political entrepreneurs - KNIPT Secretary Amsterdamski and KNIPT Chairman Janowski - to tie together the different reforms streams and to manage the process in such a way that blocking became nearly impossible. Moreover, from this perspective the double face of the reform - infusing new political ideas in an organizational structure largely inherited from the past system - can be seen as a skilful compromise, answering to the (mostly intellectual) requests of the opposition, while at the same time keeping the interests of the research units which were funded through the old centralistic system of research programs.

\section{From lock-in to a new reform}

The reforms of 1991 were followed by a decade of stability, where only minor adaptation of the research policy institutions took place. This is in sharp contrast to the patterns shown in countries such as Estonia and the Czech Republic, where reforms were more gradual and took places during most of the 1990s (Lepori et al, 2009).

\section{The reforms of 1991 were followed by a decade of stability, in sharp contrast to the patterns shown in Estonia and the Czech Republic, where reforms were more gradual and took places during most of the $1990 \mathrm{~s}$}

The institutional set-up and funding arrangements were also immune to suggestion of more important change, including recommendations of experts from international organizations (OECD, 1995) who advised structural changes. Moreover, TPKN and National Conciliatory Committee for Science Solidarity documents prepared in 1989, which made mention of the necessity for further reforms (such as the creation of a pluralist system of specialist research councils), and discussions during the TPKN meetings at the beginning of 1990 were ignored.

There are in our view at least three main reasons to explain this stability. First, while initially the KBN enjoyed rather modest support from the scientific community which, after several decades of authoritarian regime, had little confidence in the change initiated by the new government even if democratically elected, the reform was quickly seen as satisfactory by the scientific community itself. The most often-mentioned advantages were: competitive funding of the best quality research, uniform criteria of review and greater freedom in deciding about the research topics (Jabłecka, 1995). Even if the stakeholders criticized some solutions or procedures, the advantages were more important than deficiencies. In a way, the benchmark for assessing the reform was the Communist system and thus it was clear that the new system was preferable; only later, comparison with other countries showed that organizational models were possible. Collective learning of a broader range of solutions required time and more intensive confrontation with other countries.

Second, one should emphasize the coherency and stability of the advocacy coalition supporting this model. Thus, the composition of the KBN clearly favored representation of institutional and disciplinary interests, which were themselves beneficiaries of funding decisions. The double role of the KBN in policy formulation and in the allocation of resources provided these interest groups with control on the policy framework driving the funding decisions, as well as a strong incentive against delegating funding decisions to autonomous agencies. Stability of key people on the posts of chairman and secretary of the KBN also characterized this phase.

Third, stability can be seen as a side effect of dramatic change, since the set-up of the new funding 
system took several years in a trial-and-error process. Faced with the costs of learning the new system, actors had thus relatively little resources to invest in promoting new changes. Moreover, the uncertainty about the effects of the reform meant that it was difficult to ground proposals of change in some kind of evidence and this hindered the KBN chairman from any change requiring legislative process. As Amsterdamski et al put it in 1994:

in the present situation in the country, and given the current composition of parliament, it is not likely that any amendments of the relevant laws will help to speed up the reform process. Quite the contrary in fact: it is very likely that such amendments will freeze this process and in some cases even reverse it. (Amsterdamski et al, 1994: 35)

\section{Reforms in a new context}

The most recent phase of change was triggered by an external event, namely the new Constitutional Law of 1997 , which required that responsibility for political decisions had to be assumed by the parliament, the government or ministries and not by a collegial body such as the KBN. This opportunity was seized by the KBN chairman to assume most decision-making power and to reduce the $\mathrm{KBN}$ to an advisory body to the Minister of Science. Even strong opponents of the ministerial model could not protest against argumentation connected to the establishment of legal order. While the entrepreneurial ability of the KBN chairman made possible this change of path, one would argue that bringing back political authorities was an inevitable step in the development of a mature research policy, which (with different settings) has taken place in almost all developed countries.

The progressive stabilization of the Polish State and the growth of a democratic society and of a market economy progressively created the ground for breaking the lock-in in the KBN model, which was based on vested interest but did not answer to some basic requirements of mature research policies. The progressive opening of Poland and more frequent exchanges with western European countries were relevant in this process, most reforms in the following years being motivated by the need to adopt models similar to other European countries.

The process of reform was also different from in 1989-1991: it was more gradual and based on a wide consultation of actors and building consensus around shared solutions. The three ministers of science during this period had the lead in this process, but avoided direct confrontation with $\mathrm{KBN}$ interests and made large use of juridical arguments and comparisons with other countries to motivate the reform. Confrontation was not on paradigms - the basic principle of autonomy of science and of scientific quality were not in question — but on functions and organizational structures, like the need to separate the functions of Minister of Science and Science Council Chairman; in the KBN model the minister was not a reliable partner to other ministries as a representative of science but without formal authority.

Not only did this make confrontation and policy learning between different groups easier, as policy learning theories predict, but also it made it impossible for KBN members to hide their interests behind the ideological debate on the autonomy of science. In the last round of the consultation process almost all consulted organizations stressed overall support for changes on condition that the principles of selective funding of research grants and selective funding of research institutions based on a peer-review process or evaluation procedures of scientific excellence would be preserved. Thus, giving back the power in research policy design to the minister should be counterbalanced by a progressive delegation of funding decisions to independent agencies.

Graduality of this process was also crucial to overcome the fears of scientific institutions, which trusted the KBN. It started in 2002 with delegation of funding of goal-oriented projects from small and medium-sized enterprises, and continued in 2004 with strategic research programs, while only in the last phase responsibility will be delegated for the most sensible area, namely the grant system for basic research projects.

\section{Conclusions}

Conclusions can be discussed at two different levels, one pertaining to the characteristics of the transition in central and eastern European countries in the field of research policy and one looking to more general lessons on the evolution of research policies overall.

What emerges from our case study on Poland is that the reform process after the breakdown of the Communist regime was strongly rooted in the national context of the country, in its history and in existing institutions and organizational forms both from the pre-Communist and from the Communist regimes. At least at the level of the overall design of research policy, transfer of solutions experimented in other countries was mostly limited to some general ideas (such as the research council and the 'Republic of Science'), which were, however, essentially used to legitimate arrangements inherited from domestic history. There are some good reasons to explain this institutional bricolage. Urgency meant that time and resources for a wider debate on different solutions was impossible. The isolation of the country under the Communist regime meant that knowledge of other countries' models was limited to a few personal experiences of scientists who had stays abroad (not necessarily in the most recent years). Finally, coherently with policy learning theories, the fundamental character of the reform made 
learning difficult, while change in policy rationales was brought about essentially by changes in the coalition at the power. On the contrary, the parallel setup of new funding instruments, where the issue was more technical and there was less urgency to finalize the new solutions, was characterized by a more systematic process of learning where different models from other countries were compared and adapted to the specific context of the country.

This leads to a slightly different interpretation of the reform process from a path-dependency perspective: while it is true that an external shock - the breakdown of the Communist regime - triggered a paradigmatic change, the repertoire of solutions available to actors to generate a new path was severely limited and bound to the specific context of the country. This might help to explain why, at least in this first phase, central and eastern European countries (CEECs) displayed strong divergence in the organization of their research policies (Lepori et al, 2009).

A further relevant factor was that reforms in research policy took place in a phase where the political organization of the country was also in a transition phase, with some elements of the new democratic policy regime coexisting with habits, culture, institutions and procedural rules inherited from the Communist system. Even revolutions are less abrupt than it might appear at first glance; while the basic institutions of policy can be replaced quickly, procedural rules and organizational structures of sectoral policies require a longer time and thus decision-making processes are likely to fall back to preexisting arrangements. Moreover, some of them might well become the predecessors of the new institutions and thus have a lasting impact (such as KNIPT in research policy). Further, the Polish case provides evidence that the deep layer of basic institutional arrangements, which had been embodied in long-standing practices under the Communist regime, strongly impacted on collective actors' behavior despite explicit commitments to democracy and scientific freedom. Thus, admittedly, the reform of Polish research policy was a highly centralized and undemocratic process, where open debate was largely suppressed through procedural rules, authority and claims of the urgency of the situation.

\section{Even revolutions are less abrupt than it might appear at first glance; while the basic institutions of policy can be replaced quickly, procedural rules and organizational structures of sectoral policies require a longer time}

Looking to the evolution in the following years, the specificity of the Polish case, if compared to countries such as Estonia and the Czech Republic, was that the reform led to a lock-in situation, where no further reforms were undertaken for almost a decade. Historical analysis displays that this was the (unintended) result of different factors:

- Fears that reforms would entail the risk of coming back to the old system;

- The coherency of the advocacy coalition at the power centre, as an outcome of realizing the ideal of the 'Republic of Science'; and

- The lack of a clear institutional separation between the design of policy, the allocation of funding and the beneficiaries, meaning that those who benefited from the funding system at the same time controlled the reform process.

In a way, this reflects the idealist character of the 'Republic of Science' model, but also the priority set by some reformers (especially Amsterdamski) in changing the basic rationale of science policy; the way interest and power relations were handled privileged this objective against the design of a system able to evolve and redistribute power across time.

However, in broader perspective, during the lockin phase the ground was prepared for the following reforms. We can identify three main processes at work:

1. The consolidation of the Polish state, progressively developing sectoral policies and, consequently, ministerial authority in these domains.

2. A broader acceptance of the irreversibility of the reforms, thus switching the focus from avoiding falling back into the Communist regime to improving the new institutions.

3. Increased confrontation with western European models and normative pressure from the European Union.

In this account, the normative dimension of international policy transfer clearly emerges: solutions from abroad are adopted not because they are superior to those in place nationally, but because of conformity to the institutional environment.

Again, an external event - the new Constitutional Law of 1997 - triggered the reform. The action of the ministers of science was relevant in managing the process in a gradual way and in reaching consensus. However, in a broader view, one could affirm that many features of the Polish research policy - such as the exclusion of political actors from the process, the centralization in the KBN of most decision-making both concerning policy design and funding, and the lack of delegation to an intermediary body - were too singular in the context of the models adopted in western European countries. Thus, stability of path has to be always referred to the acceptable space of solutions. This 
suggests that in a world of increasing interdependency historical analysis of the path development for individual countries needs to be integrated with a thorough analysis - both functional and normative - of the space of potential solutions and of its evolution across time. This would allow distinguishing between stable and potentially unstable paths, where, as in the Polish case, change might be generated by external events or by repositioning the whole country in the international context (in this case becoming a full member of the European Union).

A final remark concerns the role of policy entrepreneurs in the whole reform process of Polish research policy. In fact, this would seem a typical case where individuals, thanks to the breakdown of existing structures, are given very great room to maneuver to reform the system according to their own ideas. However, when one goes from the punctual analysis of the heroic reform period towards a broader historical perspective, the importance of structural factors re-emerges and, to a large extent, these have been embodied and enacted through the entrepreneurs themselves. Their function would seem more in facilitating and managing the reform process than in influencing its direction.

In our view, there are two relevant factors in this context: first, the breakdown of the Communist regime was so unexpected that reformers hardly had the time (at least concerning research policy) to develop in advance a broad repertoire of solutions and, second, CEECs were confronted - both in the general organization of society and in research policy with a strong system of beliefs and institutional arrangements in the (highly successful) market economies, which largely drove the direction of the reforms (a process further strengthened through rapid integration into the European Union). Breaking down the Communist order did not mean falling into a void space in which to design an alternative solution, but rather getting attracted by a stronger model and thus having limited possibilities of choice.

\section{References}

Amsterdamski, S 1993. Perceptions of Dilemmas: Summary of a Qualitative Study. Vienna: Institute fur die Wissenschaften vom Menschen (TERC5).

Amsterdamski, S and J Jabłecka 1993. Higher Education and Research in Poland: the Inherited Situation and the Reforms. Vienna: Institute fur die Wissenschaften vom Menschen (TERC1).

Amsterdamski, S, I Białecki, E Chmielecka and J Jabłecka 1994. Report on the reform of higher education and research in Poland. Issues in Transition, Institute of Human Sciences, Vienna, TERC Program, 7, 13-36.

Argyris, C and D A Schon 1978. Organizational Learning: a Theory of Action Perspective. Reading, Massachusetts: AddisonWesley.

Arthur, W B 1989. Competing technologies increasing returns and lock in by historical events. Economic Journal, 99, 116-131.

Bonaccorsi, A 2007. Better institutions vs better policies in European science. Science and Public Policy, 34(5), June, 303-316.
Braun, D 2003. Lasting tensions in research policy making - a delegation problem, Science and Public Policy, 32(5), October, 309-321.

Braun, D and M Benninghoff 2003. Policy learning in Swiss research policy - the case of the national centres of competence in research. Research Policy, 32(10), 1849-1863.

Cohen, M, J March and J Olsen 1972. A garbage can model of organizational choice. Administrative Science Quarterly, 17, March, 1-25.

Collier, R B and D Collier 1991. Shaping the Political Arena: Critical Junctures, the Labor Movement and Regime Dynamics in Latin America. Princeton: Princeton University Press.

Cox, R 2001. The social construction of an imperative: why welfare reform happened in Denmark and the Netherlands but not in Germany. World Politics, 53, 163-198.

David, D 1985. Clio and the economics of querty. American Economic Review, 75, 332-337.

Djelic, M and S Quack 2007. Overcoming path dependency path generation in open systems. Theory and Society, 36(2), 161-186.

Dolowitz, D P and D Marsh 2000. Learning from abroad: the role of policy transfer in contemporary policy making. Governance, 13(1), 5-24.

Findeisen, W 1993. Założenia do aktów prawnych dotyczących nauki, szkolnictwa wyższego i działalności badawczo- rozwojowej (opracowanie z grudnia 1989). Nauka Polska, Jej Potrzeby Organizacja I Rozwój, 2 (XXVIII). Warszawa, Fundacja Popierania Nauki.

Goldstein, J and R Keohane 1993. Ideas and foreign policy : an analytical framework. In Ideas and Foreign Policy, eds. J Goldstein and R Keohane. Ithaca, NY: Cornell University Press.

Greener, I 2002: Understanding NHS reform: the policy transfer, social learning and path dependency perspectives. Governance, 15(2), 161-183.

Hall, P 1993. Policy paradigms, social learning and the state: the case of economic policy making in Britain. Comparative Politics, 25(3), 275-296.

Hall, P and R Taylor 1996. Political science and the three institutionalisms. Political Studies, 44, 936-957.

Heclo, H 1974. Modern Social Politics in Britain and Sweden: from Relief to Income. New Haven: Yale University Press.

Jabłecka, J 1992. System grantów czyli konfrontacja założeń z realiami. Sprawy Nauki, 6, 3-10.

Jabłecka, J 1995. The changes of the management and financing of the research system in Poland. Social Studies of Science, 4, special issue, $727-753$.

James, $O$ and M Lodge 2003. The limitations of policy transfer and lesson drawing for public policy research. Political Studies Review, 1, 179-193.

Kingdon, J 2003. Agendas, Alternatives and Public Policies. New York/San Francisco/Boston: Longman.

Lepori, B, J Masso, J Jabłecka, K Sima and K Ukrainski 2009. Comparing the organization of public research funding in Central and Eastern European countries. Science and Public Policy, this issue.

Mahoney, J 2000. Path dependence in historical sociology. Theory and Society, 29(4), 507-548.

Małkowski, S 1992. Postulaty z dziedziny nauki. Nauka Polska, Jej Potrzeby Organizacja I Rozwój, 1 (XXVII). Warszawa: Fundacja Popierania Nauki.

McCubbins, Mathew D, Roger G Noll and Barry R Weingast 1987. Administrative procedures as instruments of political control. Journal of Law, Economics and Organization, 3(2), 243-277.

North, D 1990. Institutions, Institutional Change and Economic Performance. Cambridge: Cambridge University Press

OECD, Organization for Economic Cooperation and Development 1995. Reviews of National Science and Technology Policy Poland, Part Two, Examiners Report.

Olsen, J P and B G Peters 1996. Lessons from Experience: Experiential Learning in Administrative Reforms in Eight Democracies. Oslo: Scandinavian University Press.

Peters, G 1995. Institutional Theory in Political Science: the 'New Institutionalism'. London: Continuum.

Pierson, P 2000. Increasing returns, path dependence and the study of politics. American Political Science Review, 94, 251-267.

Polanyi, M 1962. The republic of science, its political and economic theory. Minerva, Autumn, 54-73. Reprinted in Criteria for Scientific Development, Public Policy and National Goals, ed. E Shils. Cambridge, MA: MIT Press. 1968. 
Rose, R 1993. Lesson Drawing in Public Policy. Chatham, NJ: Chatham House.

Sabatier, P 1987. Knowledge, policy-oriented learning and policy change. Knowledge, Diffusion, Utilization, 8(4), 649-692.

Scott, R, P Mendel and C Caronna 2000. Institutional Change and Healthcare Organizations: from Professional Dominance to Managed Care. University of Chicago Press.

Smith, A 2002. Policy Transfer in the Development of UK Climate Policy for Business. SPRU Electronic Working Paper Series, Paper no. 75, January.

Stacey, J and B Ritterberger 2003. Dynamics of formal and informal institutional change. Journal of European Public Policy, 10(6), 858-873.

Stark, D and L Burszt 1992. One way or multiple paths for a comparative sociology of East European capitalism. American Journal of Sociology, 4, 1129-1137.
Steinmo, S, Kathleen Thelen and F Logstreth 1992. Structuring Politics: Institutionalism in Comparative Analysis. Cambridge University Press.

Stone, D 2000. Learning Lessons, Policy Transfer and the International Diffusion of Ideas. Centre for the Study of Globalisation and Regionalisation.

Sydow, J and J Koch 2005. Organizational Paths: Path Dependency and Beyond. Free University of Berlin, Faculty of Economics and Administration, 21st EGOS Colloquium, 30 June2 July, Berlin.

Thelen, K 1999. Historical institutionalism in comparative politics. Annual Review of Political Sciences, 2, 369-404.

Thelen, K 2003. How institutions evolve: insights from comparative historical analysis. In Comparative Historical Analysis in Social Sciences, eds. J Mahoney and D Rueschemeyer. New York: Cambridge University Press. 